\title{
Intracellular Sorting of Neuromodulin (GAP-43) Mutants Modified in the Membrane Targeting Domain
}

\author{
Yuechueng Liu, Daniel A. Fisher, and Daniel R. Storm \\ Department of Pharmacology, University of Washington School of Medicine, Seattle, Washington 98195
}

Neuromodulin (GAP-43) is a neurospecific calmodulin binding protein that is targeted to neuronal growth cones via fast axonal transport by an undefined mechanism. The protein is associated with membranes by palmitoylation of cys -3 and cys-4. The objective of this study was to examine the intracellular localization of neuromodulin and neuromodulin mutants modified in the membrane targeting domain of the protein in neurons and non-neuronal cells. The $\mathbf{N}$-terminal palmitoylation domain of neuromodulin was found to be sufficient for membrane and Golgi targeting as well as neurite transport. A fusion protein consisting of the $\mathrm{N}$-terminal 20 amino acids of neuromodulin and $\beta$-galactosidase accumulated in neurite endings demonstrating that this sequence is sufficient for targeting to growth cone membranes. Mutations in the palmitoylation domain of neuromodulin that abolished its acylation and membrane association diminished its Golgi localization. Mutations that prevented Golgi accumulation of neuromodulin- $\beta$-galactosidase fusion proteins also interfered with neurite transport of the fusion proteins. These data demonstrate a correlation between membrane targeting, Golgi localization, and neurite transport of neuromodulin.

[Key words: neuromodulin, GAP-43, Golgi apparatus, growth cone, protein sorting]

Protein sorting into specific subcellular compartments is essential for normal cellular functions in neurons. During axonal outgrowth and regeneration, newly synthesized proteins are sorted and delivered to different locations in neurons, including axonal and dendritic processes. Axonally transported proteins have been shown to move along axons at different rates (reviewed by Grafstein and Forman, 1980; Skene, 1989). Fasttransported proteins (groups I and II) are generally transported into axons within hours of their synthesis (Willard et al., 1974; Grafstein and Forman, 1980), whereas slow-transported protcins (groups IV and $V$ ) require days to reach their destination (Black and Lasek, 1980). It has been suggested that fast-transported proteins are packaged in Golgi apparatus with the membranous vesicles, which are coupled to anterograde microtubuledependent motor proteins such as kinesin (Pfister et al., 1989; Schroer and Sheetz, 1991; Ferreira et al., 1992). Disruption of Golgi-related functions with monensin or brefeldin A inhibits

\footnotetext{
Received Nov. 18, 1993; revised Mar. 21, 1994; accepted Apr. 6, 1994.

We thank Dr. Brian Seed for providing pCDM8 plasmid. This work was supported by NIH Grant GM 33708 to D.R.S. and NSF Grant IBN 9119975 to Y.L.

Correspondence should be addressed to Dr. Daniel R. Storm, Department of Pharmacology, SJ-30, University of Washington, Seattle, WA 98195.

Copyright @ 1994 Society for Neuroscience $0270-6474 / 94 / 145807-11 \$ 05.00 / 0$
}

fast axonal transport (Hammerschlag et al., 1982; Smith et al., 1991). Although it is not clear how fast-transported proteins are sorted in the Golgi networks, it has been suggested that the transported proteins may contain specific "recognition sequences" that allow them to undergo selective sorting and packaging in the Golgi apparatus (Hammerschlag et al., 1982).

Neuromodulin (also known as GAP-43, P-57, B-50, and F1) is transported to growth cones by fast axonal transport (Skene and Willard, 1981; Benowitz and Lewis, 1983). The protein is a major protein kinase C substrate in neurons (Akers and Routtenberg, 1987; Alexander et al., 1987; Apel et al., 1990). In vitro studies have shown that protein kinase $\mathrm{C}$ phosphorylation of neuromodulin inhibits its interaction with calmodulin (CaM), which may play a significant role in calcium/CaM-mediated signal transduction pathways in neurons (Andreasen et al., 1983; Alexander et al., 1987; Liu et al., 1990). During axonal growth and regeneration, neuromodulin synthesis is increased severalfold, suggesting its involvement in growth associated processes in neurons (Skene and Willard, 1981; Benowitz and Lewis, 1983; Skene and Willard, 1983). In addition, the protcin may play a role(s) in long-term potentiation (Akers and Routtenberg, 1987) and neurotransmitter release (Dekker et al., 1989; Ivins et al., 1993).

Neuromodulin is a major component of membranes isolated from whole brain and growth cone membranes (Cimler et al., 1985; Skene et al., 1986). The protein is tightly associated with membranes through fally acylation of its cysteines at positions 3 and 4 (Skene and Virag, 1989; Chapman et al., 1992; Liu et al., 1993). Immunofluorescence localization of the protein in cultured neurons has shown that it is distributed throughout neurite processes and cell bodies during the early developmental stages, and gradually becomes concentrated in distal regions of neurites and growth cones (Meiri et al., 1988; Burry et al., 1991). Neuromodulin has also been shown to be associated with the Golgi apparatus in PC12 cells and cultured hippocampal neurons (Van Hooff et al., 1989; Goslin et al., 1990). Therefore, passage through the Golgi apparatus may be an obligatory step for the transport of neuromodulin into neurites.

It has been shown that sorting of membrane proteins in neurons may be similar to mechanisms for sorting in non-neuronal cells (Dotti and Simons, 1990). Many of the fast axonally transported proteins are integral membrane proteins that are translated from ER-associated ribosomes, translocated into the Golgi apparatus, where they undergo posttranslational modifications and enter different membrane pathways (Klausner et al., 1992; Rothman and Orci, 1992). Neuromodulin, however, is translated by free ribosomes as a cytosolic protein and subsequently becomes membrane bound through posttranslational palmitoylation (Skene and Virag, 1989). Little is known about the mech- 
A)

Neuromodulin Point Mutant

\begin{tabular}{ll}
\hline $\mathbf{W t}$ & 1 MLCCMRRTKQ... \\
$\mathbf{T 2}$ & MTCCMRRTKQ... \\
$\mathbf{T 3}$ & MLTCMRRTKQ... \\
$\mathbf{L 3}$ & MLLCMRRTKQ... \\
$\mathbf{L 4}$ & MLCLMRRTKQ... \\
$\mathbf{R 5}$ & MLCCRRRTKQ... \\
$\mathbf{2 G}$ & MLGGMRRTKQ... \\
\hline
\end{tabular}

B)

Neuromodulin Fusion Constructs

NMf-B-gal

Figure 1. Diagram of neuromodulin and neuromodulin- $\beta$-galactosidase cDNA subcloned into the pCDM8 plasmid. anisms for the delivery of neuromodulin to membranes or the sites within the cell where palmitoylation of neuromodulin occurs. Previous studies have shown that downregulation of kinesin expression by antisense oligonucleotides abolished axonal transport of neuromodulin (Ferreira et al., 1992). This observation suggests that neuromodulin may undergo microtubuledependent, Golgi-derived vesicular transport. The present study focuses on the molecular events that lead to the targeting of neuromodulin to the Golgi apparatus in cultured rat embryonic neurons and non-neuronal cells. It has been demonstrated that both cultured neurons and non-neuronal cells provide useful systems for investigating the intracellular targeting (Liu et al., 1991) and posttranslational modifications of neuromodulin (Skene and Virag, 1989; Zuber et al., 1989; Chapman et al., 1992). It was the objective of this study to characterize the structural elements of neuromodulin that direct the protein to the Golgi apparatus and to neurite growth cones.

\section{Materials and Methods}

Plasmid construction. The fusion cDNA clones $\mathrm{NM}_{-}-\beta$-gal, $\mathrm{NM}_{\mathrm{c}}-\beta$-gal, $\mathrm{NM}_{10}-\beta$-gal, and $\beta$-gal control (see Appendix for abbreviations) were subcloned into the expression vector pCDM8 (a gift from Dr. Brian Seed, Massachusetts General Hospital) as described previously (Liu et al., 1991). Mutagenesis of the N-terminal amino acid sequence of neuromodulin was accomplished by PCR to amplify a 525 bp fragment encoding the 5 ' sequence of the protein. PCR products were digested with HindIII and NaeI to generate a $300 \mathrm{bp}$ fragment that was subsequently ligated to pCDM8-NM at the HindIII and NaeI sites (Liu et al., 1991). The PCR primers used were, upstream, T2: 5'-GGGGAAGCTTACCATGACGTGCTGTATGAGAAGAACCA-3'; T3, 5'-GGGGAAGCTACCATGCTGACCTGTCTGAGAAGAACCA-3'; L3, 5'-GGGGAAGCTTACCATGCTGCTCTGTATGAGAAGAACCA-3'; L4, 5'-GGGGAAGCTTACCATGCTGTGCTTAATGAGAAGAACCA-3'; R5, 5'-GGGGAAGCTTACCATGCTGTGCTGTAAGAGAAGAACCA-3'; and downstream primer, 5'-TGCTTTCTGCAGTCTCCGTTGGA-3'. Deletion of neuromodulin sequence was achieved by PCR, which generated a product with a PstI restriction site at the $3^{\prime}$ end and an HindIII site at the $5^{\prime}$ of the coding region of the protein. The PCR fragment was ligated to the lac $\mathrm{Z}$ gene by replacing the full-length neu-

A)

\section{Neuromodulin}

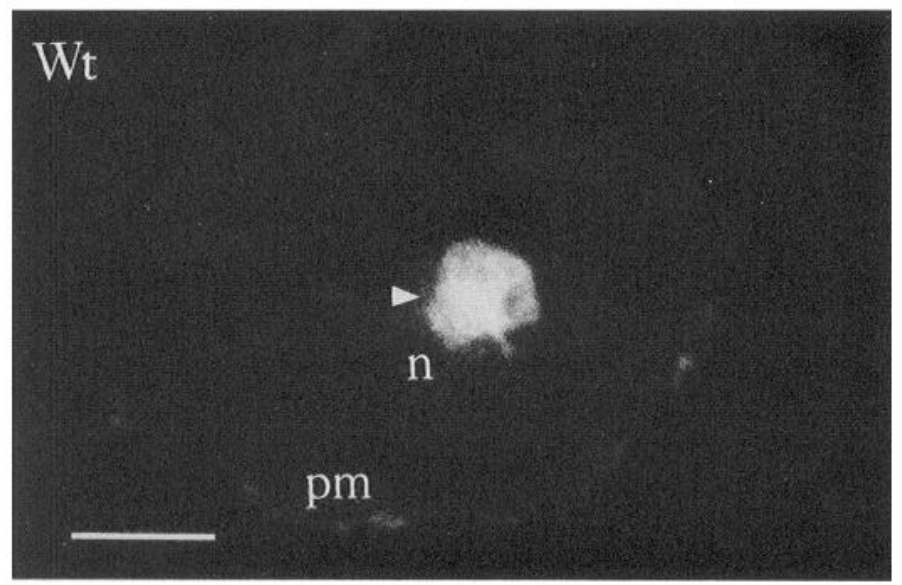

WGA

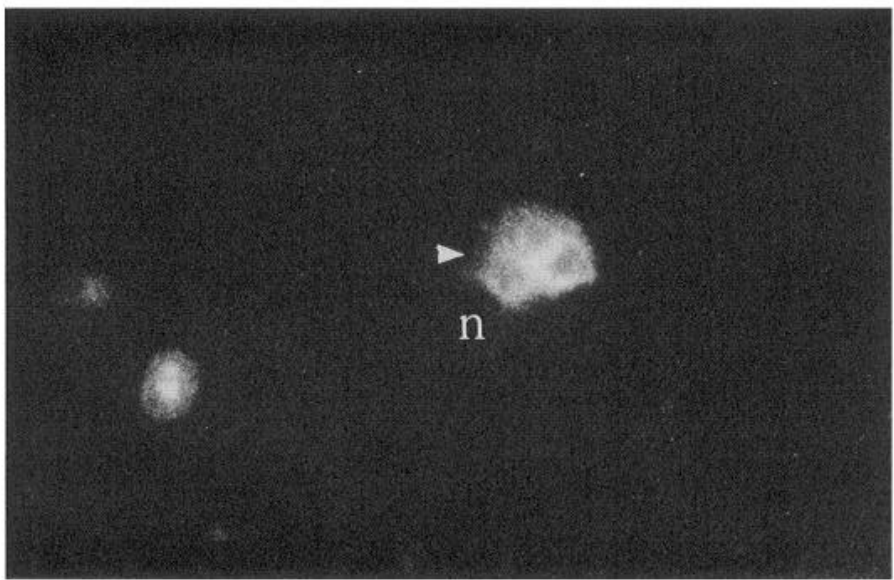

Figure 2. Immunofluorescence localization of neuromodulin expressed in COS-7 cells. COS-7 cells were transfected using DEAE dextran method and stained with a mouse monoclonal antibody against neuromodulin $(2 \mu \mathrm{g} / \mathrm{ml}$; clone $91 \mathrm{E} 12$, Boehringer-Mannheim) and an FITC-conjugated horse anti-mouse secondary antibody (1:1500; Pierce). Golgi complex was identified by staining with TRITC-conjugated WGA (4 $\mu \mathrm{g} / \mathrm{ml}$; Sigma). $W t$, wild-type neuromodulin; $T 2$, leu- 2 to thr- $2 ; T 3$, cys- 3 to thr- $3 ; L 3$, cys- 3 to leu- $3 ; L 4$, cys- 4 to leu- $4 ; R 5$, met-5 to arg-5; $2 G$, cys-3, 4 to gly3,4. $n$, nucleus; $p m$, plasma membrane. Scale bars, $15 \mu \mathrm{m}$. 
B)

Neuromodulin
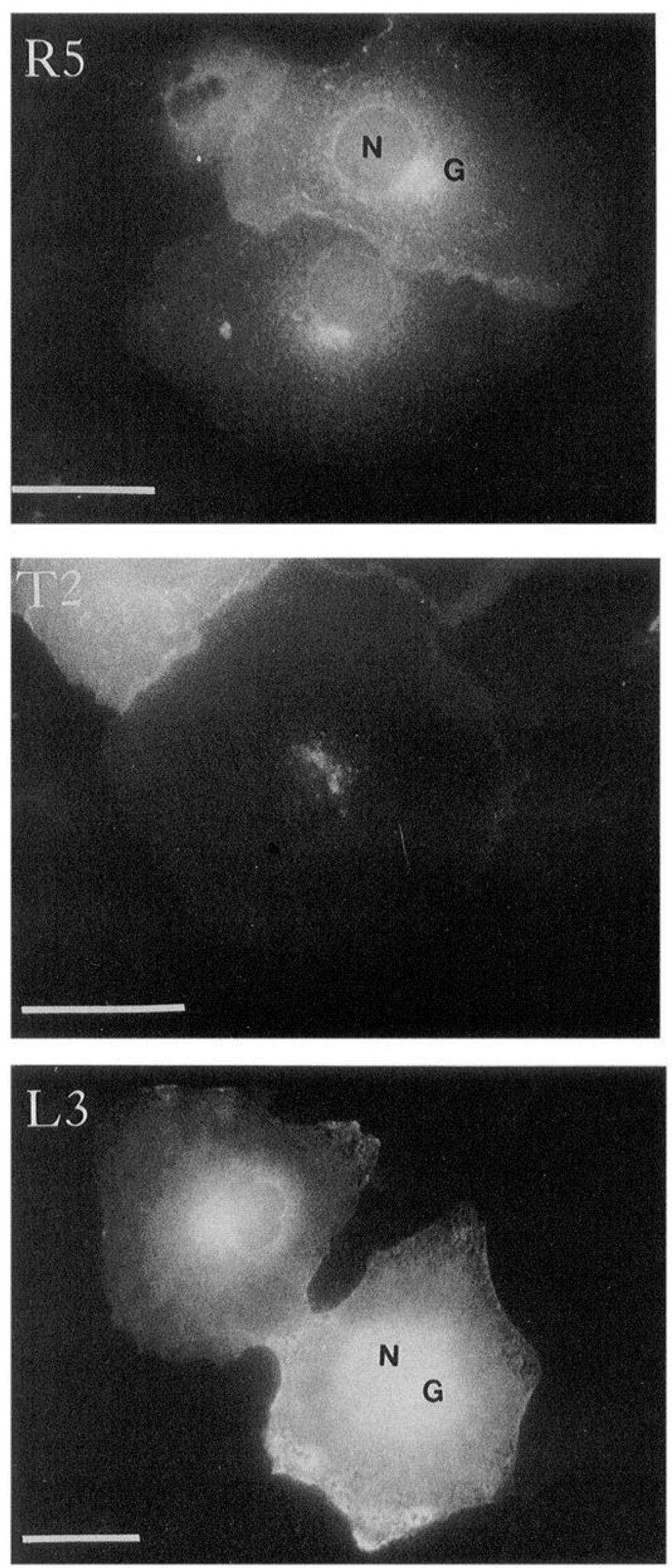

WGA
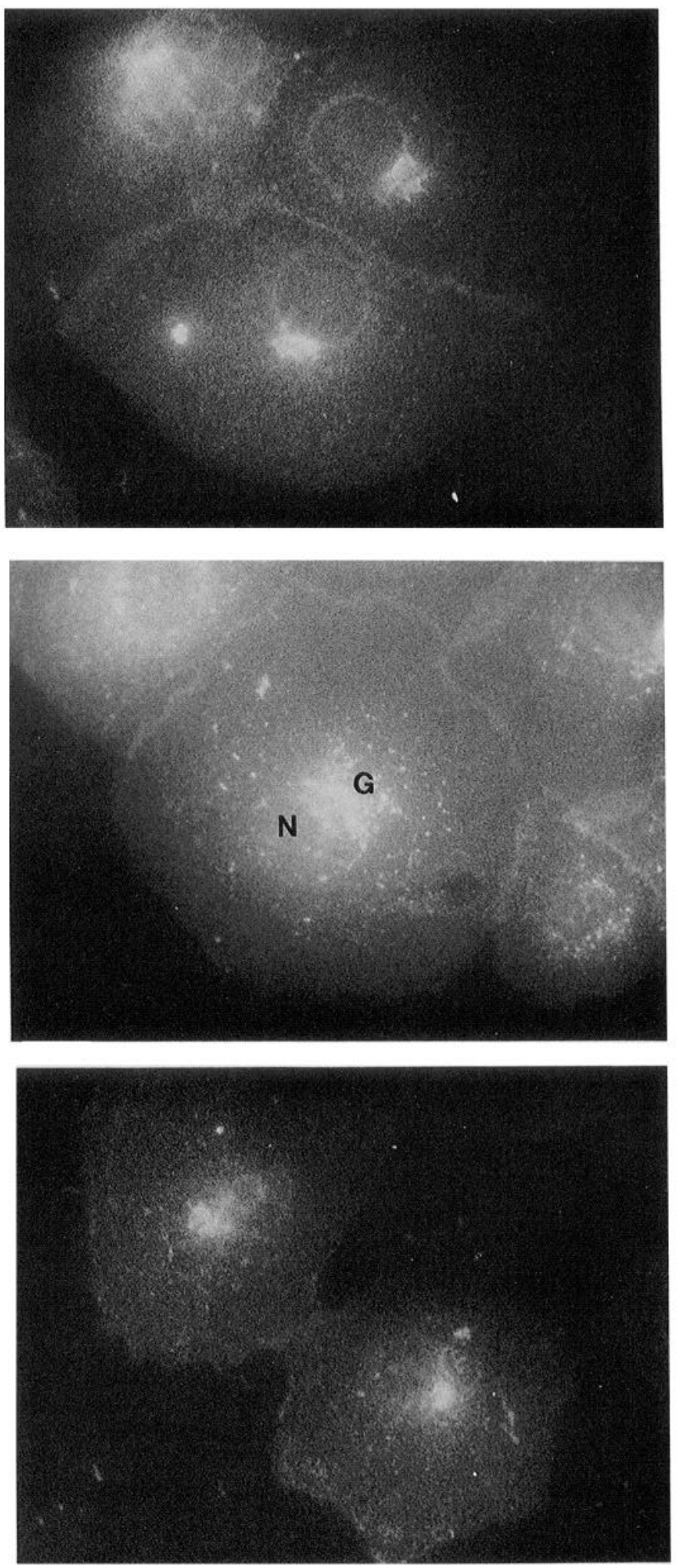
C)

Neuromodulin

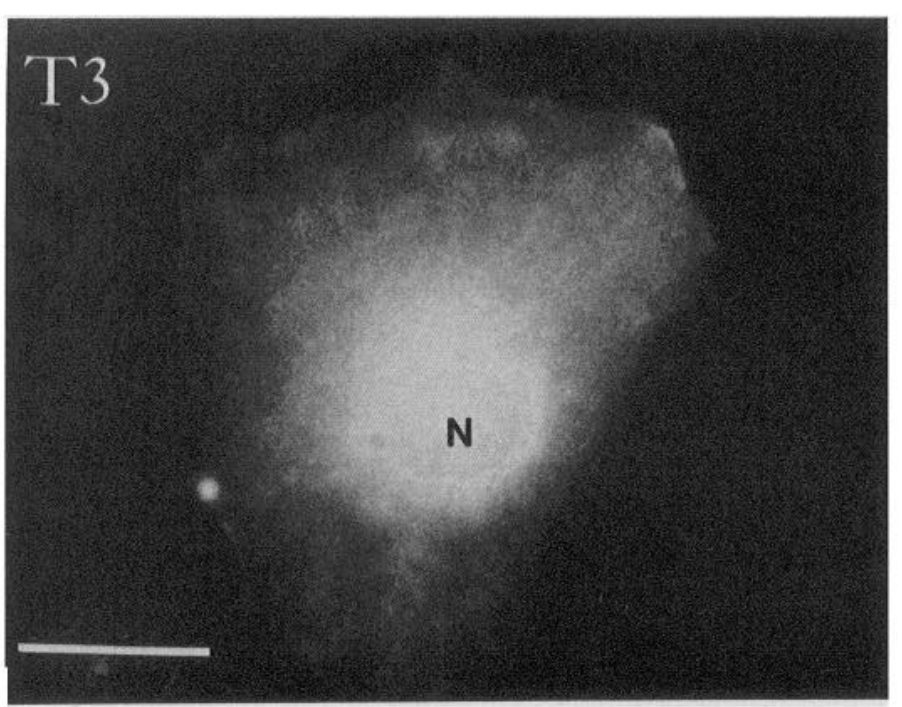

\section{L4}

WGA
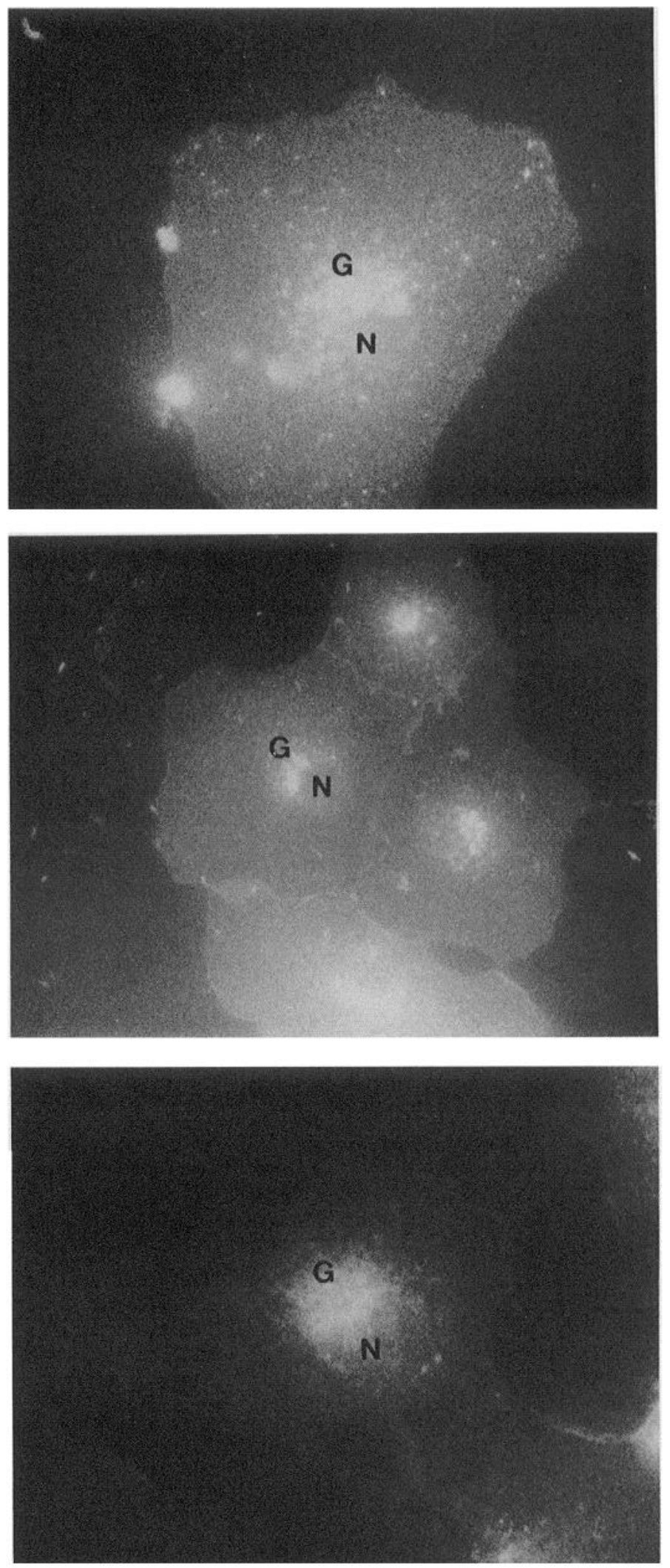

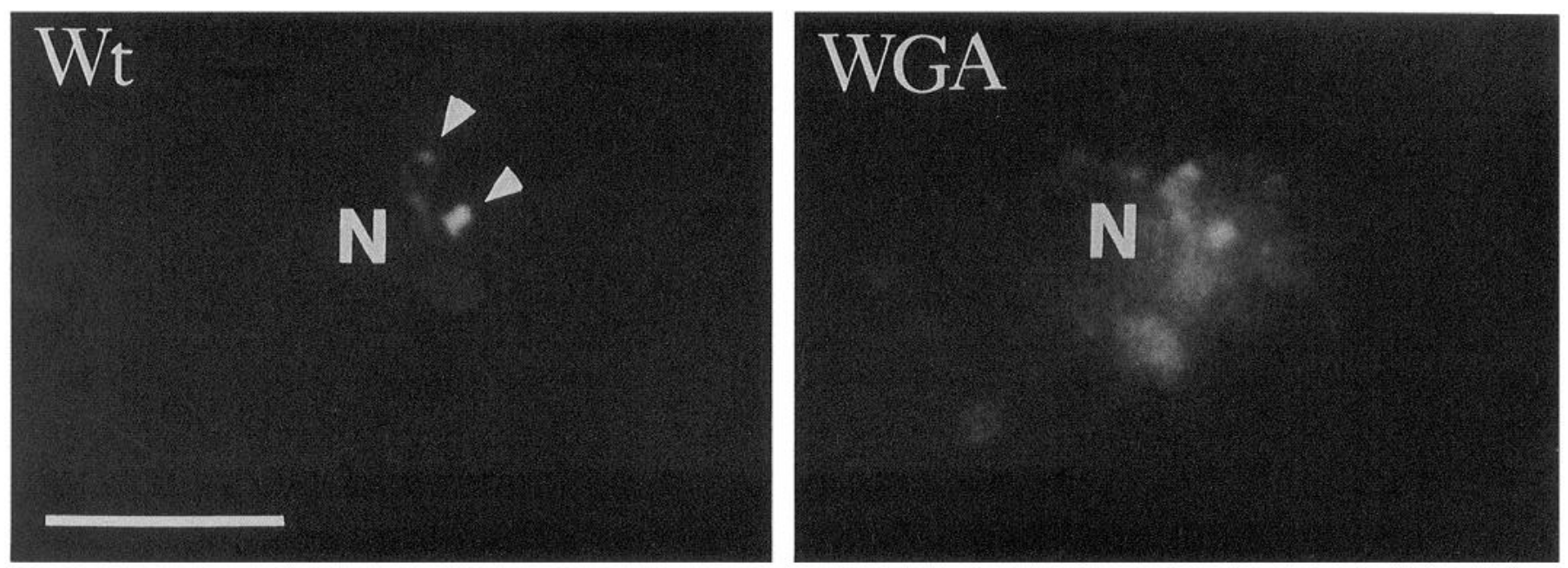

Figure 3. Immunofluorescence staining of COS-7 cells expressing wild-type neuromodulin treated with BFA. Transfected cells were treated with BFA $\left(20 \mu \mathrm{g} / \mathrm{ml}\right.$; Sigma) for $30 \mathrm{~min}$ at $37^{\circ} \mathrm{C}$ before fixing with $-20^{\circ} \mathrm{C}$ ethanol. Neuromodulin immunoreactivity was detected with antibodies as described in Figure 1. Arrowheads indicated neuromodulin immunofluorescence in the trans-Golgi network-like structures. Scale bar, $5 \mu \mathrm{m}$.

romodulin sequence (Liu et al., 1991). The PCR primers used were, upstream, 5'-GGGGGGAAGCTATCGTGTGCTGTATGAGAAGAACCAAACAG-3', and downstream, 5'-GGGGGGCTGCAGTTCTCCTTGGCCTCGGCCTCAGCAGCACCA-3'. For substitutions of arg 6,7 and lys 9 with ser 6,7 and gln 9, an upstream PCR primer 5'GGGGGGAAGCTTATGCTGTGCTGTATGAGCAGCACCCAACAG-3' was used. $\mathrm{NM}_{20}-\beta$-gal was constructed by ligation of a polylinker, 5'-GARCAAAAGAATCATGAGGACCAAAAGATTGAG-3', to the BamH1 site of $\mathrm{NM}_{10}-\beta$-gal (Liu et al., 1991). All mutations were confirmed by direct DNA sequencing.

Cell cultures and transfections. Seventeen-day-old rat embryo cortical neurons were dissociated in $20 \mathrm{~mm}$ HEPES, pH 7.5, $150 \mathrm{~mm} \mathrm{NaCl}$ (HBS), plated onto poly-L-lysine (Sigma; $50 \mu \mathrm{g} / \mathrm{mi}$ )-coated $10 \mathrm{~cm}$ dishes, and cultured in chemically defined DMEM supplemented with $5 \mu \mathrm{g} / \mathrm{m}$ insulin, $100 \mu \mathrm{g} / \mathrm{ml}$ transferrin, $20 \mathrm{nM}$ progesterone, $100 \mu \mathrm{M}$ putrescine, $1 \mathrm{~mm}$ sodium pyruvate, $30 \mathrm{~nm}$ sodium selenite, and $0.1 \%$ ovalbumin (Bottestein and Sato, 1979). The cells were maintained in a humidified $37^{\circ} \mathrm{C}$ incubator with $5 \% \mathrm{CO}_{2}$. COS-7 cells were grown in DMEM supplemented with $10 \%$ fetal calf serum. Transient expression of various neuromodulin and fusion constructs in COS-7 cells was performed using DEAE dextran methods. Cells were plated in a $10 \mathrm{~cm}$ dish at $35-40 \%$ confluency the day before transfection. Four micrograms of DNA were used for each transfection and the cells were incubated in a $35^{\circ} \mathrm{C}$ incubator for $48 \mathrm{hr}$ before collection. For the transfection of neuron cultures, dissociated neurons were plated at $1.3-2 \times 10^{6}$ cells per $10 \mathrm{~cm}$ dish. After $2 \mathrm{hr}$ in culture, lipofection (Felgner et al., 1987) was performed using $70 \mu \mathrm{g}$ of Lipofectin (Bethesda Research Labs) and $25 \mu \mathrm{g}$ of DNA in $4 \mathrm{ml}$ of HBS. After incubation for $5 \mathrm{hr}$ at $37^{\circ} \mathrm{C}$, culture media were added and the incubation was continued another $12 \mathrm{hr}$ before replacement with fresh media.

Immunohistochemical methods and immunoblot analysis. Cells were fixed with $3 \%$ paraformaldehyde in $25 \mathrm{~mm} \mathrm{Na}_{2} \mathrm{HPO}_{4}, 25 \mathrm{~mm} \mathrm{KH} \mathrm{HO}_{4}$, pH 7.4, $100 \mathrm{~mm} \mathrm{NaCl}, 1 \mathrm{~mm} \mathrm{MgCl}_{2}$, and $0.01 \% \mathrm{NaN}_{3}$ (PBS) at room temperature for $15 \mathrm{~min}$ and permeabilized with $-20^{\circ} \mathrm{C}$ ethanol for 5 min. Nonspecific binding sites were blocked with 4\% BSA in PBS for $30 \mathrm{~min}$ at room temperature. The cells were incubated overnight at $4^{\circ} \mathrm{C}$ with a monoclonal antibody against neuromodulin (clone 91E12, Boehringer-Mannheim; $2 \mu \mathrm{g} / \mathrm{ml}$ ) or rabbit anti- $\beta$-galactosidase (Cappel; $3 \mu \mathrm{g}$ ) $\mathrm{ml})$. After washing the cells with PBS, rhodamine-conjugated secondary goat anti-rabbit IgG (Boehringer-Mannheim; 1:1500) or FITC-conjugated horse anti-mouse IgG (Pierce; $1: 1500$ ) was incubated for $1 \mathrm{hr}$ at room temperature. In some case, a tertiary antibody was used to amplify the fluorescent signal. For staining of Golgi apparatus, cells were incubated with TRITC-conjugated WGA (Sigma; $4 \mu \mathrm{g} / \mathrm{ml}$ ) in solutions with the secondary antibodies. Photography was done using a Leitz Dialux 20 fluorescence microscope equipped with a Leitz Vario Orthomat camera system.

For $\beta$-galactosidase activity assays, transfected COS- 7 cells were scraped off of the plates and collected by sedimentation at $3000 \times g$ for $5 \mathrm{~min}$.
The cell pellet was resuspended in ice-cold Tris- $\mathrm{HCl}, \mathrm{pH} 7.5,2 \mathrm{~mm}$ EDTA, and 1 mM PMSF and homogenized on ice. Nuclei and unbroken cells were separated by centrifugation at $4000 \times \mathrm{g}$ for $2 \mathrm{~min}$. Cytosol and membranes were prepared by centrifugation at $100,000 \times g$ for 40 $\min$ in an Airfuge. $\beta$-Galactosidase activity was assayed using $O$-nitrophenyl- $\beta$-D-galactopyranoside as a substrate according to Pardee et al. (1959). One unit of $\beta$-galactosidase activity $=1000 \times\left[A_{420 \mathrm{~nm}}-\right.$ $\left.1.75\left(A_{550 \mathrm{~nm}}\right)\right] / T_{\min }$. The assay was performed at $35^{\circ} \mathrm{C}$ for $30 \mathrm{~min}$.

\section{Results}

\section{Neuromodulin localization in Golgi apparatus}

The Golgi apparatus of cultured cells can be localized and labeled by wheat germ agglutinin (WGA), a lectin that labels the Golgi region with little or no staining of the endoplasmic reticulum (Virtanen et al., 1990; Willemer et al., 1990). The presence of neuromodulin in the Golgi apparatus has also been reported for PC1 2 cells (van Hooff et al., 1989), cultured rat hippocampal neurons (Goslin et al., 1990), and cortical neurons (Liu and Storm, unpublished observation). In order to define structural elements of neuromodulin required for membrane targeting, Golgi sorting, and neurite transport, we characterized the localization of wild-type and mutant neuromodulins transiently expressed in COS-7 cells (Fig. 1). COS-7 cells were chosen because of their easily identifiable Golgi apparatus. Wild-type neuromodulin expressed in COS-7 cells has been shown to be

\section{Table 1. Localization of neuromodulin in COS-7 cells}

\begin{tabular}{lr} 
Neuromodulin & $\begin{array}{l}\text { Golgi localizatio } \\
(\%)\end{array}$ \\
\hline Wt & $72(n=112)$ \\
T2 & $75(n=60)$ \\
T3 & $16(n=66)$ \\
L3 & $53(n=38)$ \\
L4 & $22(n=69)$ \\
R5 & $68(n=38)$ \\
2G & $\mathrm{ND}^{b}(n=20)$
\end{tabular}

a The percentage of transfected COS-7 cells with strong staining of neuromodulin in the Golgi apparatus.

${ }^{b}$ Not detected. 

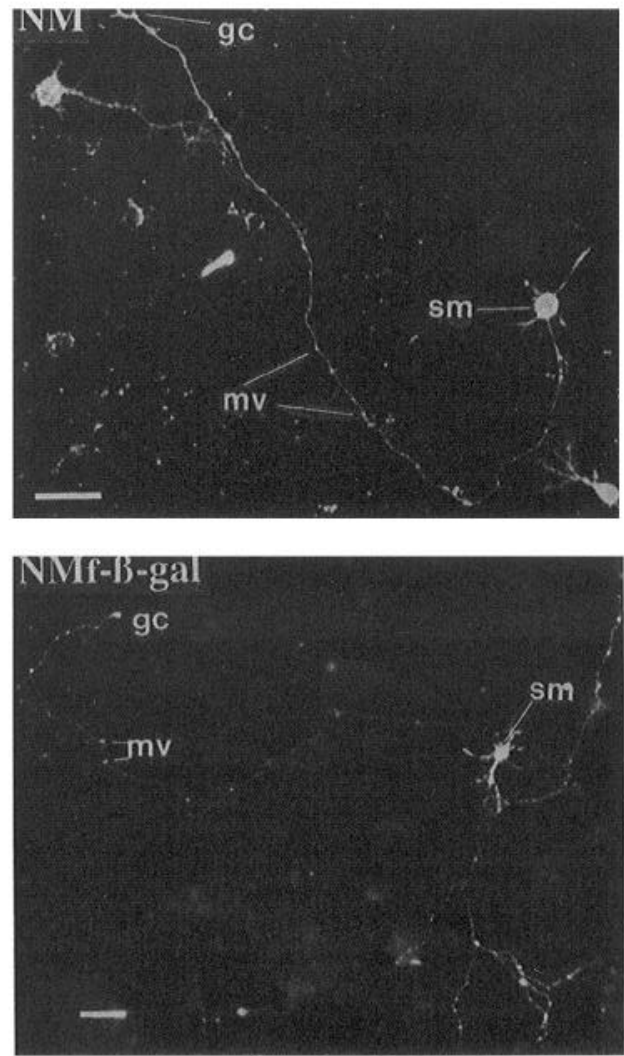

Figure 4. Immunofluorescence staining of neuromodulin, $\beta$-galactosidase, and neuromodulin- $\beta$-galactosidase fusion proteins expressed in 4-d-old cortical neurons. $N M$, endogenous neuromodulin; $\beta$-gal, $\beta$-galactosidase control; $N M_{10}-\beta$-gal, fusion protein containing the N-terminal 10 amino acids of neuromodulin; $N M_{20}-\beta$-gal, fusion protein containing the $\mathrm{N}$-terminal 20 amino acids of neuromodulin; $N M_{68(\Delta+)-}-\beta-g a l$, fusion protein containing the $\mathrm{N}$-terminal 68 amino acids of neuromodulin with arg- 6 , arg-7, and lys- 9 mutated to ser-6, ser-7, and gln-9, respectively; $N M_{\digamma} \beta$-gal, full-length neuromodulin fused to $\beta$-galactosidase. $g c$, growth cones; $m v$, multiple varicosities; $s m$, soma. Scale bars, $30 \mu \mathrm{m}$.

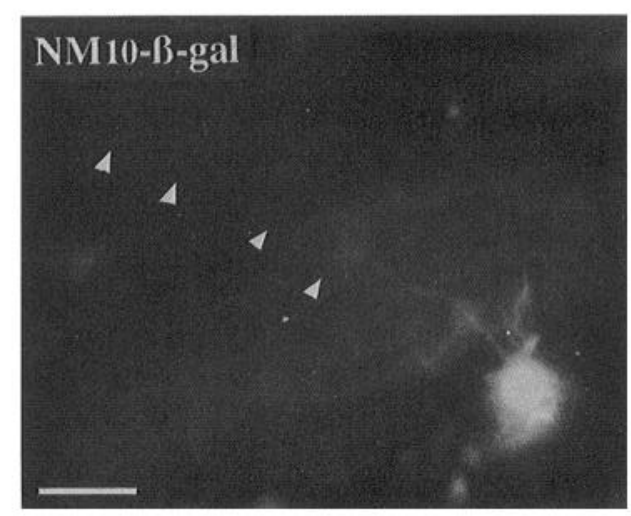

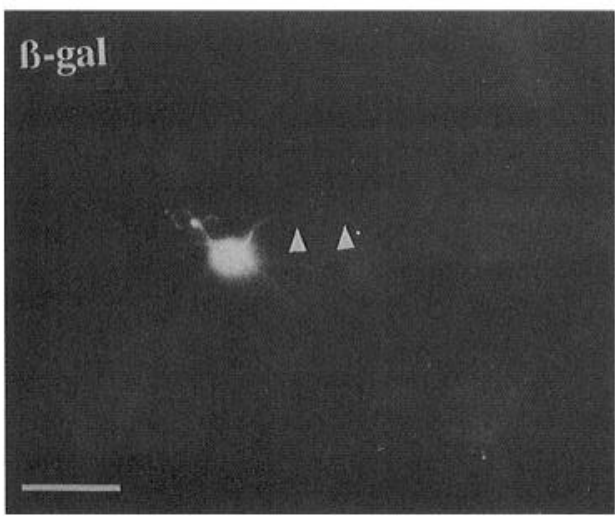
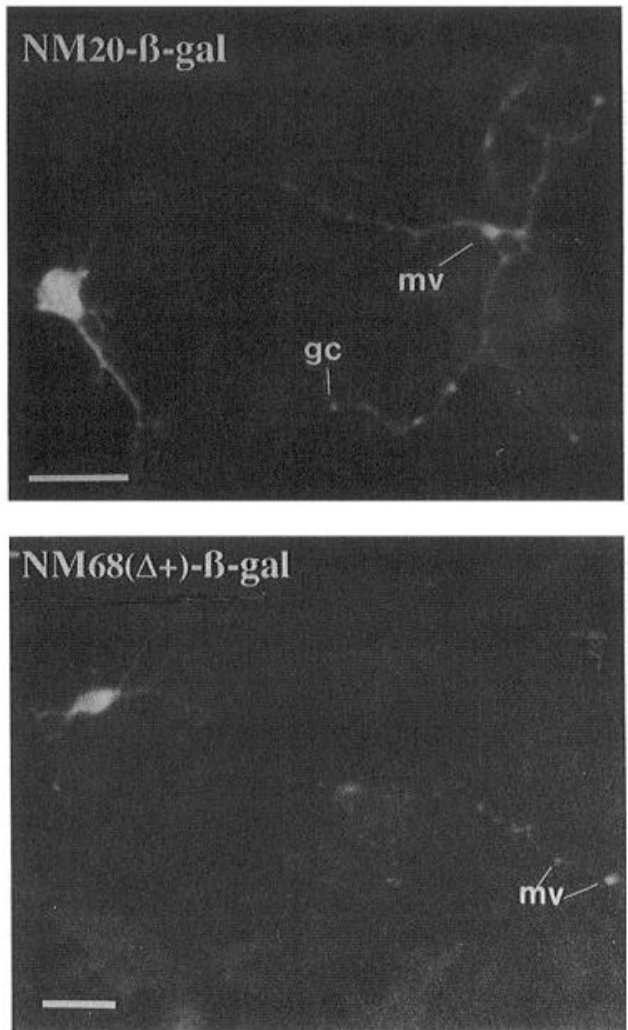

predominantly membrane bound (Liu et al., 1993). Immunofluorescence staining of the transfected cells showed intense neuromodulin immunoreactivity associated with the Golgi apparatus (Fig. 2A). Neuromodulin staining was also detectable, with less intensity and frequency, in other membranous organelles such as the nuclear envelope and endosomes. Plasma membrane staining was evident as a distinct patchy distribution at the edge of the cells (Fig. $2 A$ ). As the expression continued $48 \mathrm{hr}$ posttransfection, neuromodulin immunoreactivity was found to be accumulated at the plasma membrane and other membrane structures such as endosomes. Treatment of the cells with brefeldin A (BFA), which disrupts membrane transport from ER to Golgi, did not result in redistribution of neuromodulin into ER (Fig. 3), a phenomenon observed for many Golgi enzyme markers such as mannosidase II and galactosyl transferase (Klausner et al., 1992). As shown in Figure 3, while substantial amount of WGA staining was redistributed into ER-like struc- tures, neuromodulin immunofluorescence was restricted primarily to the trans-Golgi network (TGN)-like structures.

\section{Golgi localization of neuromodulin requires palmitoylation and membrane association}

Neuromodulin associates with cellular membranes via palmitoylation of cys-3 and cys-4 (Skene and Virag, 1989; Chapman et al., 1992). A more detailed analysis of this phenomenon using individual point mutations at cys- 3 or cys- 4 has suggested that cys- 4 is the major site for palmitoylation whereas cys- 3 is a minor palmitoylation site (Liu et al., 1993). We have also shown that the degree of membrane binding by neuromodulin correlated with the extent of palmitoylation of the cysteine residues, suggesting that palmitoylation is necessary for its membrane association (Liu et al., 1993).

When the $2 \mathrm{G}$ mutant (cys 3,4 to gly 3,4 ) was expressed in COS-7 cells, it showed diffuse cytosolic staining uniformly around 

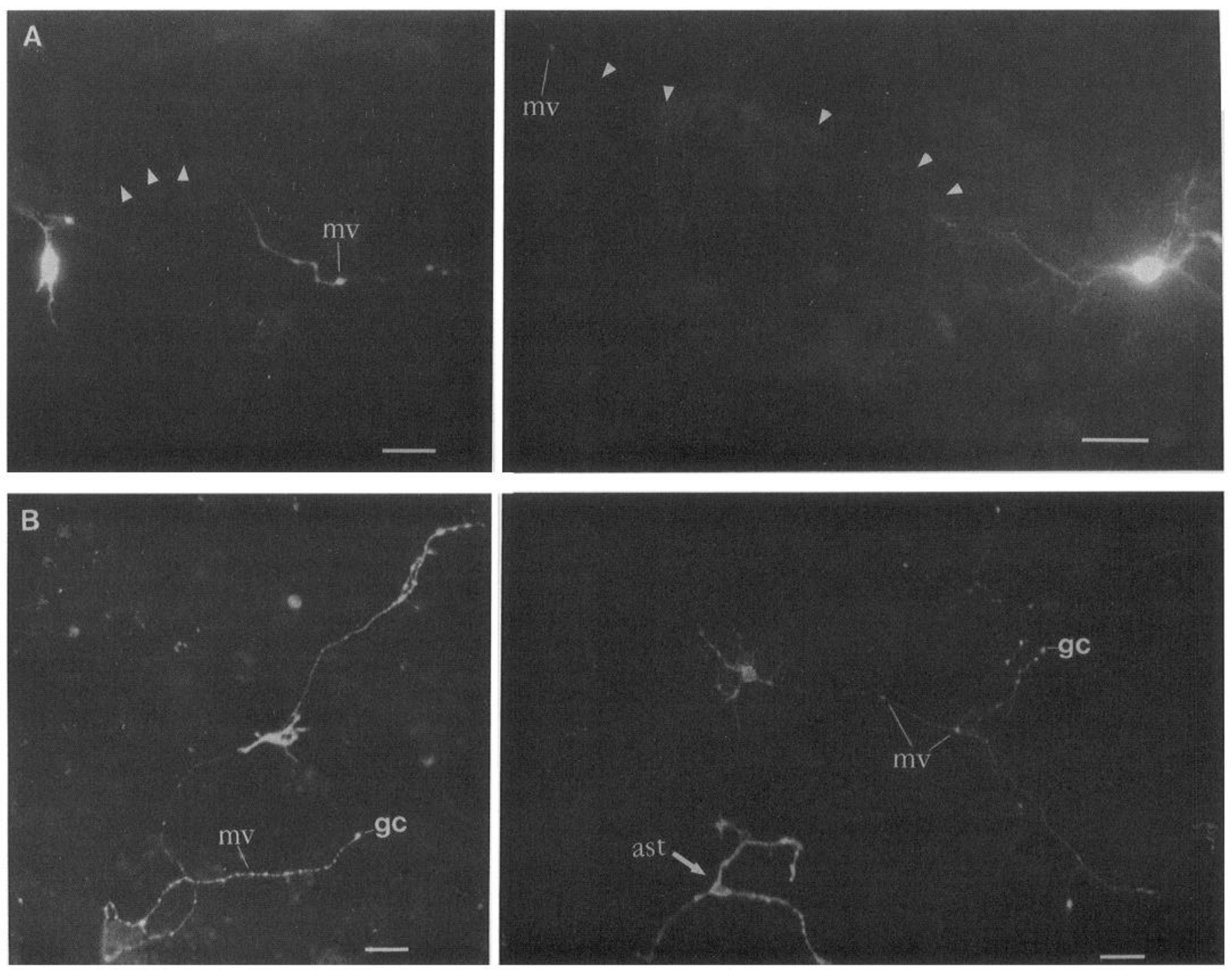

Figure 5. Immunofluorescence localization of $\mathrm{NM}_{2 \mathrm{G}}-\beta$-gal and $\mathrm{NM}_{\mathrm{r}}-\beta$-gal expressed in 4-d-old cortical neurons. $A$, $\mathrm{NM}_{2 \mathrm{G}}-\beta$-gal; $B$, $\mathrm{NM}_{r}-\beta$-gal. Arrowheads indicate the processes that were faintly stained. gc, growth cones; $m v$, multiple varicosities; ast, a transfected astrocyte. Scale bars, $30 \mu \mathrm{m}$.

the nucleus without Golgi localization (Fig. 2C, Table 1). L3 (cys-3 to leu-3) showed a Golgi and plasma membrane staining pattern resembling that of the wild-type protein (Fig. 2B, Table 1), while L4 (cys-4 to leu-4) showed diffuse cytoplasmic staining around the nucleus similar to that seen for the $2 \mathrm{G}$ mutant (Fig. $2 C$ ). T3 (cys-3 to thr-3) strongly resembled L4, showing a substantial reduction in Golgi localization (Fig. 2C). Point mutations of several amino acid residues in the membrane binding domain other than the cysteines did not significantly altered Golgi accumulation. For example, T2 and R5 showed Golgi localization and membrane association (Fig. $2 B$, Table 1). These data indicate that palmitoylation and membrane targeting of neuromodulin correlate with accumulation of the protein in the Golgi.

The transport of neuromodulin fusion proteins into neurites correlates with Golgi sorting and membrane targeting

To determine if Golgi sorting of neuromodulin is required for its transport and growth cone accumulation, we transfected pri-
Table 2. Localization of expressed fusion proteins in neurons and COS-7 cells

\begin{tabular}{lcc} 
Plasmid & $\begin{array}{l}\text { Axonal staining } \\
(\%)\end{array}$ & \multicolumn{1}{l}{$\begin{array}{l}\text { Golgi } \\
\text { localization }^{b} \\
(\%)\end{array}$} \\
\hline$\beta$-gal & $2(n=26)$ & $1(n=156)$ \\
$\mathrm{NM}_{10}-\beta$-gal & $2(n=28)$ & $18(n=115)$ \\
$\mathrm{NM}_{20}-\beta$-gal & $77(n=49)$ & $61(n=222)$ \\
$\mathrm{NM}_{68(\Delta+)}-\beta$-gal & $35(n=39)$ & $30(n=176)$ \\
$\mathrm{NM}_{68}-\beta$-gal & $70(n=30)$ & $\mathrm{ND}^{c}$ \\
$\mathrm{NM}_{2 \mathrm{G}}-\beta$-gal & $12(n=24)$ & $6(n=178)$ \\
$\mathrm{NM}_{\mathrm{r}}-\beta$-gal & $82(n=30)$ & $90(n=311)$
\end{tabular}

${ }^{a}$ The percentage of transfected neurons showing immunofluorescence staining in axons. Neurons with processes having neuromodulin- $\beta$-gal fusion proteins concentrated in the distal regions and with punctate staining patterns along processes were scored as positive.

${ }^{b}$ The percentage of transfected COS-7 cells with strong staining of neuromodulin in the Golgi apparatus.

c Not done. 


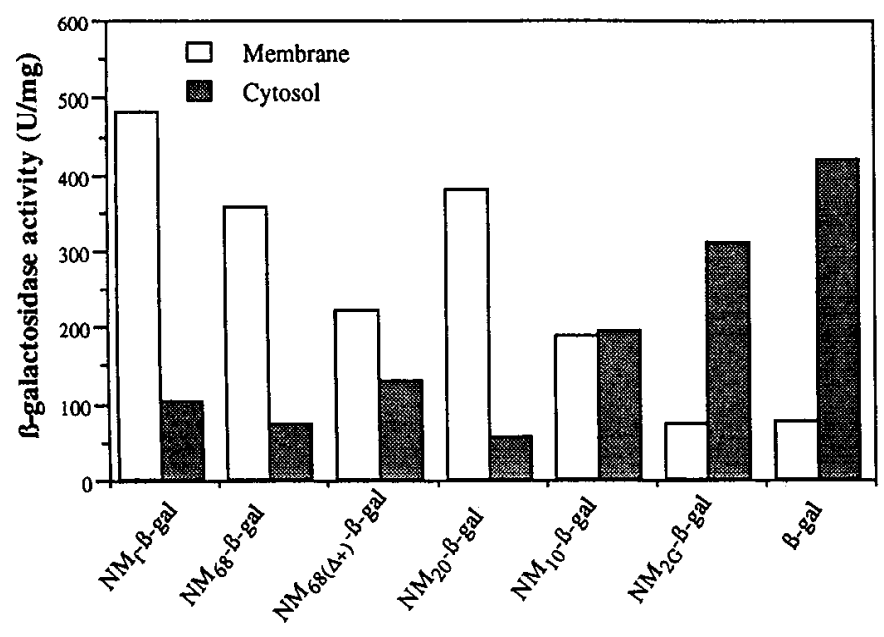

Figure 6. Distribution of neuromodulin- $\beta$-galactosidase fusion proteins between the membrane and cytosolic fraction of COS-7 cells. COS-7 cells expressing the fusion proteins were fractionated into membrane and cytosolic fractions and assayed for $\beta$-galactosidase activity as described in Materials and Methods.

mary cultured rat embryonic neurons with several neuromodulin- $\beta$-galactosidase cDNA fusion constructs. The intracellular location of the fusion proteins was analyzed using an antibody against $\beta$-galactosidase. The endogenous neuromodulin was distributed in the cell body and through both dendritic and axonal processes, often with intense staining in the growth cones and multiple varicosities (Fig. 4). This is consistent with previous reports for the distribution of neuromodulin in cultured rat sympathetic neurons (Meiri et al., 1988), rat hippocampal neurons (Goslin et al., 1988), spinal cord neurons (van der Neut et al., 1991), and cerebellar neurons (Burry et al., 1991). When $\beta$-galactosidase was expressed in neurons it was detectable in cell bodies but not in neurites, multiple varicosities, or growth cones (Fig. 4, Table 2). The fusion protein consisting of fulllength neuromodulin and $\beta$-galactosidase, $N \mathrm{~N}_{\mathrm{f}}-\beta$-gal, showed a similar distribution in cultured neurons with intense signals in the growth cones and multiple varicosities (Fig. 4, Table 2). Two truncated fusion proteins containing $\mathrm{N}$-terminal sequences from neuromodulin, $\mathrm{NM}_{68}-\beta$-gal and $\mathrm{NM}_{20}-\beta$-gal, showed a distribution very similar to endogenous neuromodulin and the fulllength neuromodulin fusion protein (Fig. 4, Table 2). These data indicated that the $\mathrm{N}$-terminal 20 amino acid sequence of neuromodulin is sufficient for neurite and growth cone targeting of neuromodulin- $\beta$-galactosidase fusion proteins. $\mathrm{NM}_{10}-\beta$-gal, which contained only the $\mathrm{N}$-terminal 10 amino acid sequence of neuromodulin fused to $\beta$-galactosidase, showed a distribution very similar to $\beta$-galactosidase, without transport into neurites (Fig. 4, Table 2).

It has been noted that one of the common features in the palmitoylation domains is the presence of positively charged amino acids, which may contribute to the effectiveness of palmitoylation (Liu et al., 1993). In order to examine the impor- tance of positively charged amino acids in the membrane targeting domain for neurite transport, we generated a mutant neuromodulin, $\mathrm{NM}_{68(\Delta+)}-\beta$-gal, which contained the $\mathrm{N}$-terminal 68 amino acids with arg-6, arg-7, and lys- 9 mutated to ser- 6 , ser-7, and gln-9, respectively. Although $\mathrm{NM}_{68(\Delta+)}-\beta$-gal was detected in some neurites and multiple varicosities, the intensity and the frequency of the staining in these structures was considerably less than those for $\mathrm{NM}_{r}-\beta$-gal and $\mathrm{NM}_{20}-\beta$-gal (Fig. 4, Table 2). As expected, $\mathrm{NM}_{2 \mathrm{G}}-\beta$-gal was not targeted to growth cone membranes and was not localized along neurite membranes, this fusion protein was detected in some multiple varicosities at a relatively low frequency compared to $\mathrm{NM}_{\mathrm{r}}-\beta$-gal or endogenous neuromodulin (Fig. 5). It is possible that regions other than the palmitoylation domain of $\mathrm{NM}_{2 \mathrm{G}}-\beta$-gal may interact with proteins undergoing transport. A similar mechanism has been proposed for the transport of calmodulin (Koenig et al., 1985). The absence of the palmitoylation site in $\mathrm{NM}_{2 \mathrm{G}}-\beta$ gal, however, does not allow membrane deposition along the neurite shaft or in growth cones.

The neuromodulin- $\beta$-galactosidase fusion proteins described above were expressed in COS-7 cells in order to determine if they were localized to the Golgi apparatus or in membrane preparations from these cells. Neuromodulin- $\beta$-gal fusion proteins expressed in COS-7 cells had apparent molecular weights on SDS gels ranging from 120 to $150 \mathrm{kDa}$, consistent with the predicted molecular weights of the fusion proteins (data not shown). Distribution of the fusion proteins between the membrane fraction and cytosol of COS-7 cells was quantitated by assaying $\beta$-galactosidase activity (Fig. 6). As expected, $\mathrm{NM}_{\mathrm{f}}-\beta$ gal, $\mathrm{NM}_{68}-\beta$-gal, and $\mathrm{NM}_{20}-\beta$-gal showed significant accumulation in the membrane fraction relative to the cytosolic fraction, whereas $\beta$-galactosidase and $\mathrm{NM}_{2 \mathrm{G}}-\beta$-gal behaved as cytosolic proteins. Substantially less $\beta$-galactosidase activity associated with $\mathrm{NM}_{10}-\beta$-gal was found in the membranes (Fig. 6). $\mathrm{NM}_{68(\Delta+)^{-}}$ $\beta$-gal showed an intermediate level of membrane association that was significantly reduced compared to $\mathrm{NM}_{\mathrm{r}}-\beta$-gal, but was greater than that observed for $\mathrm{NM}_{10}-\beta$-gal.

The distribution of the various neuromodulin- $\beta$-galactosidase fusion proteins expressed in COS-7 cells was examined by immunofluorescencc. $\mathrm{NM}_{2 \mathrm{G}}-\beta$-gal, $\mathrm{NM}_{10}-\beta$-gal, and $\beta$-galactosidase showed a diffuse cytosolic distribution symmetrically around the nucleus, with no apparent Golgi localization (Fig. 7). In contrast, $\mathrm{NM}_{\mathrm{f}}-\beta$-gal and $\mathrm{NM}_{20}-\beta$-gal showed prominent staining in the Golgi apparatus. $\mathrm{NM}_{68(\Delta+)}-\beta$-gal showed weak Golgi localization (Fig. 7). These data suggest that the N-terminal 20 amino acid sequence of neuromodulin, and particularly the palmitoylation site, are required for its membrane association, Golgi sorting, and transport into neurites and neurite growth cones.

\section{Discussion}

Although the mechanism(s) that underlies the sorting and transport of proteins into neuronal processes has not been fully elucidated, it has been proposed that fast-transported proteins may contain "recognition sequences" that target the polypeptides to

Figure 7. Immunofluorescence localization of neuromodulin- $\beta$-galactosidase fusion proteins expressed in COS-7 cells. $\beta$-gal, $\beta$-galactosidase control; $N M_{10}-\beta$-gal, fusion protein containing the $\mathrm{N}$-terminal 10 amino acids of neuromodulin; $N M_{20}-\beta$-gal, fusion protein containing the $\mathrm{N}$-terminal 20 amino acids of neuromodulin; $N M_{68(\Delta+,}-\beta-$-gal, fusion protein containing the N-terminal 68 amino acids of neuromodulin with arg-6, arg-7, and lys-9 mutated to ser-6, ser-7, and gln-9, respectively; $N M_{f}-\beta$-gal, full-length neuromodulin fused to $\beta$-galactosidase. $G$, Golgi apparatus; $N$, nucleus; $M$, plasma membrane. Scale bar, $15 \mu \mathrm{m}$. 

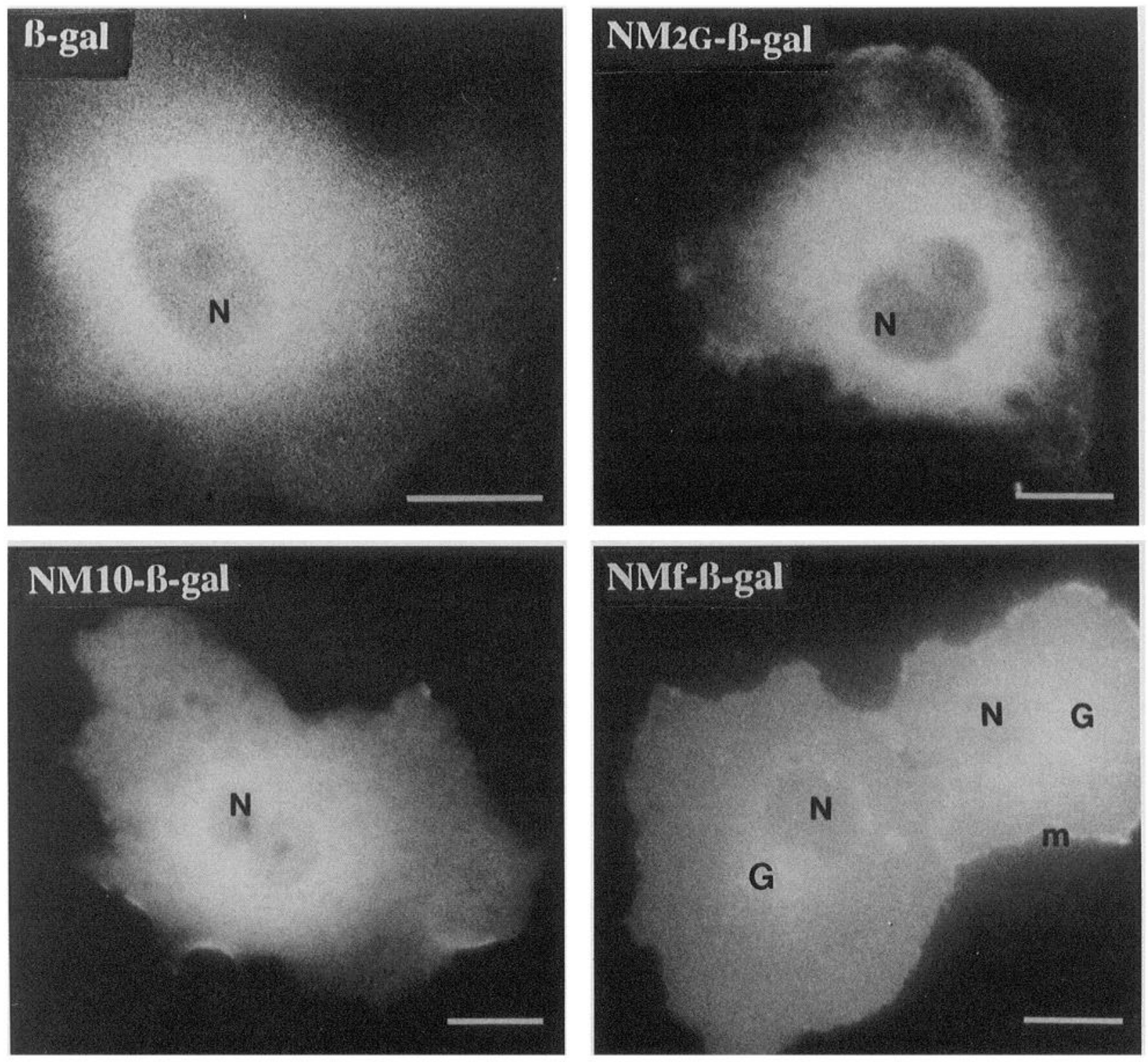

NM20-ß-gal

NM68( $\triangle+)$-B-gal

G

N

G N 
spccific rcgions of the Golgi apparatus where thcy arc packaged into membrane vesicles for delivery (Stone and Hammerschlag, 1987; Smith and Snyder, 1992). In non-neuronal cells such as the epithelial MDCK cells, proteins are sorted to different compartments of Golgi stacks and are recruited to either the apical or basolateral membranes (Simons and Fuller, 1985; Nelson, 1992). Similar and possibly homologous pathways may also exist in the axonal and dendritic domain-specific sorting pathways found in neurons (Dotti and Simons, 1990).

Because fast axonal transport often involves movement of membranous structures along microtubules (Smith and Snyder, 1992), it is conceivable that membrane association and axonal transport of neuromodulin may be closely related. The data in this study suggested that neuromodulin may be processed in the Golgi apparatus and that Golgi accumulation of the protein correlates with membrane association. In cultured cortical neurons, neuromodulin is translated as a cytosolic polypeptide and becomes attached to membranes shortly after its synthesis, presumably by palmitoylation of the protein (Skene and Virag, 1989). The domain responsible for the Golgi localization of neuromodulin also contains the palmitoylation and membrane binding domain, and mutation of this domain, as in the $2 \mathrm{G}$ mutant, abolished Golgi localization of the protein. Based on these observations, we concluded that the association of the protein with the Golgi apparatus is dependent on its acylation. It is possible that neuromodulin is sorted to the Golgi by its affinity for the palmitoyltransferase, which may serve as a receptor for neuromodulin in the Golgi complex. Multiple palmitoyltransferase activities have been detected in several subcellular compartments including Golgi apparatus, endoplasmic reticulum (ER) membranes, and neuronal growth cone membranes (Rizzolo and Kornfeld, 1988; Patterson and Skene, 1989; Gutierrez and Magee, 1991). The evidence that the palmitoylation domain of neuromodulin is necessary for Golgi sorting of the protein, and the strong association of neuromodulin with the Golgi apparatus but not the ER membranes (data not shown), also suggested that the most likely site for the acylation of neuromodulin is the Golgi apparatus. Moreover, since neuromodulin did not redistribute into the ER upon BFA treatment (Fig. 3 ), palmitoylation of neuromodulin may occur in the TGN. The presence of neuromodulin in the Golgi complex has also raised the question of whether it may play an active role in Golgirelated functions such as vesicle fusion (Goslin et al., 1990).

In order for neuromodulin to be effectively delivered to the neurite terminus, the protein is very likely processed and incorporated into membranous organelles budding off the transGolgi stacks. The data in the present study seemed to support this proposal. $\mathrm{NM}_{\mathrm{f}}-\beta$-gal, $\mathrm{NM}_{68}-\beta$-gal, and $\mathrm{NM}_{20}-\beta$-gal were localized to the plasma membrane and Golgi apparatus of COS-7 cells, and were transported into neurites and growth cones of cultured neurons. On the other hand, mutant neuromodulins with reduced membrane targeting and Golgi accumulation $\left(\mathrm{NM}_{10}-\beta\right.$-gal, $\mathrm{NM}_{68(\Delta+)}-\beta$-gal, and $\mathrm{NM}_{2 \mathrm{G}}-\beta$-gal) showed diminished accumulation in neurites. Since $\mathrm{NM}_{20}-\beta$-gal but not $\mathrm{NM}_{10^{-}}$ $\beta$-gal was able to target to both Golgi and neurites, the amino acid sequence between 11 and 20 may be important for Golgi and neurite accumulation. Deletion of 11-20 sequence of NM68$\beta$-gal resulted in moderate reduction in membrane binding, Golgi and neurite targeting of the fusion protein (Liu and Storm, unpublished observation), suggesting a role for this domain in palmitoylation of the protein.

In conclusion, we hypothesize that neuromodulin may be processed through the Golgi apparatus, and that it may be palmitoylated by a specific palmitoyltransferase in the Golgi that recognizes a sequence within the $\mathrm{N}$-terminal 20 amino acids of neuromodulin. Palmitoylation and membrane targeting appear to be obligatory for Golgi sorting, which is essential for its neurite transport and growth cone accumulation.

\begin{tabular}{|c|c|}
\hline \multicolumn{2}{|l|}{ Appendlx } \\
\hline$\beta$-gal & beta-galactosidase \\
\hline $\mathrm{NM}_{\mathrm{t}}-\beta$-gal & $\begin{array}{l}\beta \text {-galactosidase fusion protein containing full- } \\
\text { length neuromodulin }\end{array}$ \\
\hline $\mathrm{NM}_{2 \mathrm{G}}-\beta$-gal & $\begin{array}{l}\beta \text {-galactosidase fusion protein containing full- } \\
\text { length neuromodulin in which the cystcincs } 3 \\
\text { and } 4 \text { were substituted with glycines }\end{array}$ \\
\hline $\mathrm{NM}_{68}-\beta$-gal & $\begin{array}{l}\beta \text {-galactosidase fusion protein containing the } \\
\text { N-terminal } 68 \text { amino acid sequence of } \\
\text { neuromodulin }\end{array}$ \\
\hline $\mathrm{NM}_{68(\Delta+)}-\beta$-gal & $\begin{array}{l}\beta \text {-galactosidase fusion protein containing the } \\
\text { N-terminal } 68 \text { amino acid sequence of } \\
\text { neuromodulin with Arg-6, Arg-7, and Lys- } 9 \\
\text { mutated to Ser, Ser, and Gln, respectively }\end{array}$ \\
\hline $\mathrm{NM}_{20}-\beta$-gal & $\begin{array}{l}\beta \text {-galactosidase fusion protein containing the } \\
\text { N-terminal } 20 \text { amino acid sequence of } \\
\text { neuromodulin }\end{array}$ \\
\hline $\mathrm{NM}_{10}-\beta$-gal & $\begin{array}{l}\beta \text {-galactosidase fusion protein containing the } \\
\text { N-terminal } 10 \text { amino acid sequence of } \\
\text { ncuromodulin }\end{array}$ \\
\hline T2 & neuromodulin with a leu- 2 to thr- 2 mutation \\
\hline T3 & neuromodulin with a cys- 3 to thr- 3 mutation \\
\hline L3 & neuromodulin with a cys-3 to leu- 3 mutation \\
\hline L4 & neuromodulin with a cys- 4 to leu- 4 mutation \\
\hline & neuromodulin with a met- 5 to arg- 5 mutation \\
\hline ONPG & $o$-nitrophenyl- $\beta$-galactopyranoside. \\
\hline
\end{tabular}

\section{References}

Alexander KA, Wakim BT, Doyle GS, Walsh KA, Storm DR (1988) Identification and characterization of the calmodulin binding domain of neuromodulin, a neurospecific calmodulin binding protein. J Biol Chem 263:7544-7549.

Andreasen TJ, Luetje CW, Heideman W, Storm DR (1983) Purification of a novel calmodulin binding protein from bovine cerebral cortex membranes. Biochemistry 22:4615-4618.

Benowitz LI, Lewis ER (1983) Increased transport of 44,000 to 49,000dalton acidic proteins during regeneration of the goldfish optic nerve: a two-dimensional gel analysis. J Neurosci 3:2153-2163.

Black MM, Lasek RJ (1980) Slow components of axonal transport: two cytoskeletal networks. J Cell Biol 86:616-623.

Bottenstein JE, Sato GH (1979) Growth of a rat neuroblastoma cell line in serum-free supplemented medium. Proc Natl Acad Sci USA 70:514-519.

Burry RW, Lah JJ, Hayes DM (1991) Redistribution of GAP-43 during growth cone development in vivo; immunocytochemical studies. J Neurocytol 20:133-144.

Chapman ER, Estep RP, Storm DR (1992) Palmitoylation of neuromodulin (GAP-43) is not required for phosphorylation by protein kinase $\mathrm{C}$ in vivo. J Biol Chem 267:25233-25238.

Cimler BM, Andreasen TJ, Andreasen KI, Storm DR (1985) P-57 is a neural specific calmodulin-binding protein. J Biol Chem 260:1078410788.

Cimler BM, Giebelhaus DH, Wakim BT, Storm DR, Moon RT (1987) Characterization of murine cDNAs encoding P-57, a neurospecific calmodulin-binding protein. J Biol Chem 262:12158-12163.

Dekker LV, De Graan PNE, Ocstreicher AB, Versteeg DHJ, Gispen WH (1990) Inhibition of noradrenaline release by antibodies to B-50 (GAP-43). Nature 342:74-76.

Dotti CG, Simons K (1990) Polarized sorting of viral glycoproteins to the axon and dendrites of hippocampal neurons in culture. Cell 62:63-72.

Felgner PL, Gadek TR, Holm M, Roman R, Chan HW, Wenz M, Northrop P, Ringold GM, Danielsen M (1987) Lipofection: a highly efficient, lipid-mediated DNA-transfection procedure. Proc Natl Acad Sci USA 84:7413-7417.

Ferreira A, Niclas J, Vale RD, Banker GA, Kosik KS (1992) Sup- 
pression of kinesin expression in cultured hippocampal neurons using antisense oligonucleotides. J Cell Biol 117:595-606.

Goslin K, Schreyer DJ, Skene JHP, Banker GA (1988) Development of neuronal polarity: GAP-43 distinguishes axonal from dendritic growth cones. Nature 336:672-674.

Goslin K, Schreyer DJ, Skene JHP, Banker GA (1990) Changes in the distribution of GAP-43 during the development of neuronal polarity. J Neurosci 10:588-602.

Grafstein B, Forman DS (1980) Intra-cellular transport in neurons. Physiol Rev 60:1167-1283.

Gutierrez L, Magee AI (1991) Characterization of a acyltransferase acting on $\mathrm{p} 21^{\mathrm{N} \text {-ras }}$ protein in a cell-free system. Biochim Biophys Acta 1078:147-154.

Hammerschlag R, Stone GC, Bolen FA, Lindsey JD, Ellisman MH (1982) Evidence that all newly synthesized proteins destined for fast axonal transport pass through the Golgi apparatus. J Cell Biol 93: $568-575$.

Ivins KJ, Neve KA, Feller DJ, Fidel SA, Neve RL (1993) Antisense GAP-43 inhibits the evoked release of dopamine from PC12 cells. J Neurochem 60:626-633.

Klausner RD, Donaldson JG, Lippincott-Schwartz J (1992) Brefeldin $A$ : insights into the control of membrane traffic and organelle structure. J Cell Biol 116:1071-1080.

Koenig E, Kinsman S, Repasky E, Sultz L (1985) Rapid mobility of motile varicosities and inclusions containing $\alpha$-spectrin, actin, and calmodulin in regenerating axons in vitro. J Neurosci 5:715-729.

Liu Y, Storm DR (1990) Regulation of free calmodulin levels by neuromodulin: neuron growth and regeneration. Trends Pharmacol Sci 11:107-111.

Liu Y, Chapman E, Storm DR (1991) Targeting of neuromodulin (GAP-43) fusion proteins to growth cones in cultured rat embryonic neurons. Neuron 6:411-420.

Liu Y, Fisher DA, Storm DR (1993) Analysis of the palmitoylation and membrane targeting domain of neuromodulin (GAP-43) by site specific mutagenesis. Biochemistry 32:10714-10719.

Mciri KF, Johnson MI, Willard M (1988) Distribution and phosphorylation of the growth associated protein GAP-43 in regenerating sympathetic neurons in culture. J Neurosci 8:2571-2581.

Nelson WJ (1992) Regulation of cell surface polarity from bacteria to mammals. Science 258:948-95.

Pardee AB, Jacob F, Monod J (1959) The genetic control and cytoplasmic expression of "inducibility" in the synthesis of $\beta$-galactosidase by E. coli. J Mol Biol 1:165-178.

Patterson SJ, Skene JHP (1989) Palmitoylation of GAP-43 in intact growth cones and isolated growth cone membranes in vitro. Soc Neurosci Abstr 15:573.

Perry GW, Burmeister DW, Grafstein B (1990) Fffect of target removal on goldfish optic nerve regeneration: analysis of fast axonally transported proteins. J Neurosci 10:3439-3448.

Pfister KK, Wagner MC, Stenoien DL, Brady ST, Bloom GS (1989) Monoclonal antibodies to kinesin heavy and light chains stain vesiclelike structures, but not microtubules, in cultured cells. J Cell Biol 108: 1453-1463.
Picard D, Yamamoto K (1987) Two signals mediate hormone-dependent nuclear localization of the glucocorticoid receptor. EMBO J 6:3333-3340.

Rizzolo LJ, Kornfeld R (1988) Post-translational protein modification in the endoplasmic reticulum. J Biol Chem 263:9520-9525.

Rothman JE, Orci L (1992) Molecular dissection of the secretory pathway. Science 355:409-415.

Schroer TA, Sheetz MP (1991) Functions of microtubule-based motors. Annu Rev Physiol 53:629-652.

Skene JHP (1989) Axonal growth-associated proteins. Annu Rev Neurosci 12:127-156.

Skene JHP, Virag I (1989) Post-translational membrane attachment and dynamic fatty acylation of neuronal growth cone protein, GAP43. J Cell Biol 108:613-625.

Skene JHP, Willard M (1981) Axonally transported proteins associated with axon growth in rabbit central and peripheral nervous systems. J Cell Biol 89:96-103.

Skene JHP, Jacobson RD, Snipes GJ, McGuire CB, Norden JJ, Freeman JA (1986) A protein induced during nerve growth (GAP-43) is a major component of growth-cone membranes. Science 233:783-786.

Simons K, Fuller SD (1985) Cell surface polarity in epithelia. Annu Rev Cell Biol 1:243-268.

Smith RS, Snyder RE (1992) Relationships between the rapid axonal transport of newly synthesized proteins and membranous organelles. Mol Neurobiol 6:285-300.

Stone GC, Hammerschlag R (1987) Molecular mechanisms involved in sorting of fast-transported proteins. In: Axonal transport (Smith RS, Bisby MA, eds), pp 15-36. New York: Liss.

Strittmatter SM, Valenzuela D, Kennedy T, Neer EJ, Fishman MC (1990) $G_{n}$ is a major growth cone protein subject to regulation by GAP-43. Nature 344:836-841.

van der Neut R, Oestreicher AB, Gispen WH, Bar PR (1990) The expression of B-50/GAP-43 during development of rat spinal neurons in culture is regulated by interneuronal contact. Neurosci Lett 109: $36-41$.

Van Hooff COM, Holthuis J, Oestreicher AB, Boonstra J, De Graan PNE, Gispen WH (1989) Nerve growth factor-induced changes in the intracellular localization of the protein kinase C cubstrate B-50 in pheochromocytoma PC12 cells. J Cell Biol 108:1115-1125.

Virtanen I, Ekblom P, Laurila P (1980) Subcellular compartmentalization of saccharide moieties in cultured neuronal and malignant cells. J Cell Biol 85:429-434.

Willard M, Cowan WM, Vagelos PR (1974) The polypeptide composition of intra-axonally transported proteins: evidence for four transport velocities. Proc Natl Acad Sci USA 71:2183-2187.

Willemer S, Kohler H, Naumann R, Kern HF, Adler G (1990) Glycoconjugate pattern of membranes in the acinar cell of the rat pancreas. Histochemistry 93:319-326.

Zuber MX, Strittmatter SM, Fishman MC (1989) A membrane-targeting signal in the amino terminus of the neuronal protein GAP-43. Nature 341:345-348. 